\title{
CERAI GUGAT DAN DAMPAKNYA BAGI KELUARGA
}

\author{
Khoirul Abror \\ Dosen Fakultas Syariah UIN Raden Intan Lampung \\ J1. Endro Suratmin Sukarame Bandar Lampung \\ Email: khoirulbabror@,radenintan.ac.id
}

\begin{abstract}
Abstrak: Fenomena baru yang menjadi trend di masyarakat muslim Indonesia deewasa ini adalah, maraknya praktik cerai gugat, atas permintaan isteri ke Pengadilan Agama dalam wilayah Provinsi. Lampung; Peningkatan kasus/perkara angka cerai gugat berimplikasi pada terjadinya anggota masyarakat yang tidak diinginkan dalam sebuah keluarga; beranjak dari disharmonisasi dikalangan keluarga kecil menuju meningkat pula angka kejahatan di masyarakat; pokok permasalahannya adalah; faktor apa yang menyebabkan cerai gugat pada Pengadilan Agama di dalam wilayah Provinsi Lampung? Bagaimana dampak yang timbul akibat cerai gugat, di Provinsi Lampung?

Tulisan ini bertujuan untuk menganalisis dan menemukan faktor-faktor yang menjadi penyebab cerai gugat dan bagaimana dampak yang berimbas terhadap keluarga; Metode yang digunakan dalam menganalisis adalah analisis kualitatif yang disajikan secara deskriptif.

Hasil studi ditemukan; Pertama, Faktor utama penyebab cerai gugat yang dominan terjadi di PA Tanjungkarang, Metro, dan Kalianda, adalah faktor ekonomi, kurang atau tidak terpenuhinya kebutuhan ekonomi keluarga, tidak adanya tanggung jawab suami dalam rumah tangga, percekcokan, kekerasan dalam rumah tangga, perselingkuhan dan poligami, judi dan mabuk-mabukan. Hal ini juga disebabkan semakin meningkatnya tingkat pendidikan perempuan, kesadaran hukum, serta peluang dibolehkannya menurut UU. Kedua, dampak utama dari cerai gugat adalah terganggunya jiwa baik suami atau istri dan anggota keluarga, terlebih lagi berdampak pada anak-anak, selanjutnya berdampak bagi keberlangsungan keluarga dan sosial kemasyarakatan.
\end{abstract}

Kata Kunci: Problema Cerai Gugat, -Dampak terhadap Keluarga

\section{A. Pendahuluan}

Keutuhan dan kerukunan dalam rumah tangga yang bahagia, aman dan damai (sakinah, mawaddah warahmah) merupakan dambaan setiap orang dalam rumah tangga, bahkan perkawinan sebagai satu perjanjian (transaksi) yang kokoh, tegug dan. . Olehkarenanya setiap orang dalam

${ }^{1}$ QS. Al-Ahzâb (33) : 7; QS. An-Nisâ' (4): 21; QS. An-Nisâ' (4) : 154; Lihat, Kompilasi Hukum Islam, Pasal 2 lingkup rumah tangga dalam melaksanakan hak dan kewajibannya harus didasari oleh agama.

Perkawinan dalam Islam dikenal dengan istilah nikah atau tazwij, ${ }^{2}$ secara harfiyah adalah "bersenggama atau bercampur". Lebih lanjut Jalaluddin AlMahalli'i dalam kitabnya mengungkapkan:

\footnotetext{
2 Jalaluddin al-Mahalli, Al-Mahalli, juz III (Indonesia: Nur Asia, tt), h. 206.

3 Jalaluddin al-Mahalli, Al-Maballi, juz
} III, Ibid 
Secara syar'i nikah adalah: suatu akad yang mengandung kebolehan untuk melakukan hubungan suami isteri (hubungan seksual) dengan menggunakan lafaz "inkah" (menikahkan), atau lafaz "tazwij" (mengawinkan).

Undang-undang tentang perkawian (UU No.1 tahun 1974 Tentang Perkawinan) dan penghapusan kekerasan dalam rumah tangga ${ }^{4}$ serta Kompilasi Hukum Islam ${ }^{5}$ termasuk produk hukum negara Indonesia yang mayoritas Islam ini, wajib diketahui dan dipahami oleh seluruh masyarakat. Dengan mengetahui dan memahami UU tersebut, seluruh masyarakat seyogyanya untuk semakin menyadari hak dan kewajibannya dalam perkawinan dan Putusnya perkawinan serta akibatnya.

Salah satu tujuan perkawinan ialah ikatan lahir batin antara seorang pria dengan seorang wanita sebagai suami isteri dengan tujuan membentuk keluarga (rumah tangga) yang bahagia dan kekal berdasarkan ketuhanan Yang maha $\mathrm{Esa}^{6}$, bahkan perkawinan merupakan ikatan yang paling suci dan paling kokoh antara suami isteri. ${ }^{7}$ Selain itu juga tujuan perkawinan, untuk menghindarkan diri dari perbuatan zina, serta penerus keturunan (anak) dan juga bertujuan ibadah. ${ }^{8}$

4 Undang-undang No.23 tahun 2004 tentang Penghapusan Kekerasan dalam Rumah Tangga,.

5 Instruksi Presiden RI no. 1 tahun 1991, Kompilasi Hukum Islam, Dirjen Binbaga Islam, Kemenag RI tahun 2001

${ }^{6}$ Pasal 1 Undang-undang Perkawinan No. 1 tahun 1974

${ }^{7}$ Djamaan Nur, Figh Munakahat, Dina Utama Semarang, Cet. I, 1993, h. 130

8 Taqiyyuddin Abi Bakr, Kifayatul Akbyar fie Hilli Ghayah al-Ikbtishar, Dar alKutub al-Islamy, tt, h. 48; Lihat, Khoiruddin nasution, Hukum Perkawinan 1, ACAdeMIA, \& Tazzafa, Yogyakarta, 2005, h. 46-47.
Menurut Khoiruddin Nasution, ada sejumlah ayat yang mengisyaratkan tujuan perkawinan, yang bila disimpulkan akan tampak minimal lima tujuan umum. ${ }^{9}$ Penetapan tujuan perkawinan didasarkan pada pemahaman sejumlah nas, ayat alQur'an dan sunnah Nabi saw yang mengisyaratkan tujuan perkawinan. Sejumlah nas yang berbicara sekitar tujuan perkawinan itu; Pertama, untuk membangun keluarga sakinah; Kedua, tujuan regenerasi dan/atau pengembangbiakan manusia (reproduksi), dan secara tidak langsung sebagai jaminan eksistensi agama islam; Ketiga, bertujuan untuk pemenuhan biologis (seksual); Keempat, bertujuan nuntuk menjaga kehormatan; dan Kelima, tujuan ibadah, yang dapat dipahami secara implisit dari sejumlah ayat al-Quran dan secara eksplisit disebutkan dalam hadis.

Islam menegaskan bahwa perkawinan merupakan media untuk membentuk suatu keluarga yang tenteram dan penuh kasih sayang (sakinah mawaddah wa rabmah) berdasarkan nilai-nilai agama yang menuntut adanya interaksi saling asah, asih dan asuh diantara suami isteri. Hal ini dipertegas dalam QS. Ar-Rum (30): 21 "Dan diantara tanda-tanda kekuasaan-Nya ialah Dia menciptakan untukmu isteri-isteri dari jenismu sendiri, supaya kamu cenderung dan merasa tenteram kepadanya, dan dijadikan-Nya diantaramu rasa kasih dan sayang. Sesungguhnya pada yang

${ }^{9}$ Khoiruddin Nasution, Hukum Perdata (Keluarga) Islam Indonesia, dan Perbandingan Hukum Perkawinan di Dunia Muslim, ACAdeMIA, Tazzafa, Yogyakarta, 2009, h. 223 
demikian itu benar-benar terdapat tanda-tanda bagi kaum yang berfikir". ${ }^{10}$

Memahmi arti ayat tersebut, dapat dimengerti, bahwa salah satu tujuan perkawinan menurut Hukum Islam adalah untuk mewujudkan dan terciptanya kehidupan rumah tangga yang sakinah mawaddah wa rahmah. "

Dengan adanya ikatan perkawinan itu, diharapkan dapat melestarikan proses historis keberadaan manusia dan peradabannya dalam kehiidupan di dunia ini, yang pada akhirnya akan melahirkan keluarga sebagai unit terkecil dari kehidupan dalam sosial kemasyarakatan. ${ }^{12}$

Dibalik perkawinan yang diharapkan kekal dan abadi itu, tidaklah menutup kemungkinan apabila rumah tangga tersebut terjadi disharmonisasi, karenanya amat dimungkinkan terjdinya perselisihan, pertengkaran dan bahkan menjurus pada kekerasan diantara kedua pihak. Apabila perselisihan, pertengkaran dan kekerasan tidak dapat diatasi, maka kondisi rumah tangga akan mencapai puncak perslisihan yang mengarah kepada peceraian dan atau bubarnya perkawinan semakin menjadi kenyataan. .

Contoh kasus kekerasan fisik: terjadi pada Mar (38) yang dipukuli suami sendiri dengan menggunakan linggis hingga babak belur. ${ }^{13}$ kasus lain: terjadi pada Siti Aisyah (40) guru honorer di lampung Selatan, menjadi korban brutal suaminya sendiri Rafik (41

${ }^{10}$ Yayasan Penyelenggara Penterjemah Al-Qur'an kementerian Agama RI, AlQur'an dan Terjemabnya, Jakarta, PT. Tehazed, 2010, h. 572.

${ }^{11}$ Bab II Pasal 3, Kompilasi Hukum Islam.

12 Djamal latiief, H.M, Aneka Hukum Percerian di Indonesia, Jakarta, Ghalia Indonesia, 1982, h. 12.

13 Harian Lampung Post, Kamis, 02 Mei 2013, h. 07. tahun), sehingga mengalami 11 luka tusukan (7 di punggung, 2 di perut dan 2 di paha kanan) lantaran berpisah rumah karena alasan ekonomi,. ${ }^{14}$

Fenomena yang terjadi ditengah masyarakat muslim di Indonesia, angka perceraian semakin meningkat dikarenakan banyak faktor yang menyebabkannya. yang lebih mengherankan, bila angka perceraian didominasi atas permintaan isteri, yang lebih dikenal dengan istilah kbuluk ${ }^{15}$ (cerai gugat). Salah satu dampak yang timbul akibat perceraian ini, kesengsaraan atau penderitaan secara fisik, seksual, psikologis, dan atau penelantaran rumah tangga termasuk ancaman untuk melakukan perbuatan, pemaksaan, atau perampasan kemerdekaan secara melawan hukum dalam lingkup rumah tangga. ${ }^{16}$

Di PA Kota Metro dan Kabupaten Lampung Timur mencatat angka perceraian selama 2016 sebanyak 1.415 perkara. Dari jumlah itu sebanyak 300 perkara adalah perceraian dalam rumah tangga pegawai negeri sipil (PNS).Panitera Muda Pengadilan Agama Kota Metro Ros Amanah Rabu (15/1), mengatakan jumlah perkara yang ditangani selama 2016 sebanyak 1.415 sudah diputuskan sebanyak 1.400 perkara. "Pada bulan Desember 2016, ada 30 gugatan perceraian oleh PNS," 17

14 Harian Lampung Post, Kamis , 5 januari 2012, h. 22

15 Kbuluk; adalah perceraian yang terjadi atas permintaan isteri, dengan memberikan tebusan (Iwad, ) kepada dan atas persetujuan suami.

16 Undang-undang No.23 tahun 2004 tentang Penghapusan Kekerasan dalam Rumah Tangga, Pasal 1 ayat (1)

17 http://lampost.co/berita/pns-dimetro-dan-lamtim-banyak-yang-bercerai,

Akses 25 Okt 2014 
Di Pengadilan Agama Tanggamus, lebih mencengangkan, khusus di bulan Oktober 2014 saja terdapat 58 Rekap perkara yang diterima: 43 diantaranya perkara Cerai Gugat, 10 perkara cerai talak, dan 5 perkara lainnya. ${ }^{18}$

Tulisan ini difokuskan pada fenomena faktor-faktor penyebab Cerai Gugat yang dilakukan oleh isteri kepada suami yang berujung pada putusnya perkawinan di tiga Kabupaten-Kota di Provinsi Lampung (Kota bandar Lampung, Kota Metro dan Kabupaten Lampung Selatan) serta dampaknya bagi keluarga (suami, isteri dan anak)

\section{B. Pembahasan}

\section{Factor Penyebab Cerai Gugat}

Perceraian, selain cerai talak, dikenal juga adanya cerai gugat. Kata cerai gugat adalah istilah yang sering dikenal dengan istilah khulu'

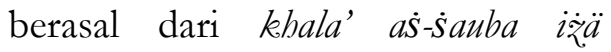
azalaba yang artinya melepaskan pakaian; karena istri adalah pakaian suami dan suami adalah pakaian istri. Kbulu' menurut bahasa, dari

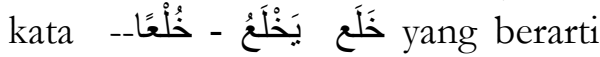
melepaskan atau menanggalkan

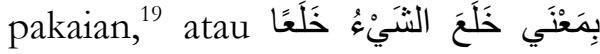
yang berarti menanggalkan ia akan sesuatu. ${ }^{20}$ Sedangkan menurut istilah, adalah menebus istri akan dirinya kepada suaminya dengan hartanya maka tertalaklah dirinya. ${ }^{21}$

18

ht://www.pa-

tanggamus.go.id/index.php/rekap-perkaraditerima, Akses 25 Oktober 2014

19 A. W. Munawwir, Al-Munawwir:

Kamus Arab-Indonesia, (Surabaya: Pustaka

Progresif, 1997), Cet. 14, h. 361

${ }^{20}$ Idris Al-Marbawi, Kamus Bahasa Arab Melayu, (Surabaya: Hidayah, 2000), Jil. 1, h. 184

21 Abu Mansur, Lisan el-Arab, (Kairo:

Daar el-Hadis, 2003), Jil. 3, h. 182
Menanggapi perihal khulu',22 mempunyai dua arti yaitu 'am dan khas. Khulu' dalam arti umum adalah talak atas harta istri untuk menebus dirinya yang diserahkan kepada suaminya baik dengan lafaz khulu' atau lafazh mubara'ah atau dengan lafaz talak; pengertian ini banyak digunakan oleh ulama kontemporer. Adapun khulu' dalam arti khas adalah talak tebus dengan lafaz khulu', pendapat ini banyak digunakan oleh ulama salaf

Secara terminologi, menurut syariat, "Khuluk ${ }^{23}$ ialah talak yang dijatuhkan sebab keinginan dan desakan dari pihak istri, hal semacam itu disyariatkan dengan jalan khuluk, yakni pihak istri menyanggupi membayar seharga kesepakatan antara dirinya dengan suami, dengan (standar) mengikuti mahar yang telah diberikan."

Berangkat dari pemaparan tersebut bisa kita pahami bahwa khuluk secara syariat hukumnya boleh diajukan jika memenuhi persyaratan. Selain itu, dalam khuluk harus terjadi kesepakatan antara kedua belah pihak, suami maupun istri tentang nominal tebusan. Kesepakatan ini sekaligus menunjukkan bahwa dalam akad khuluk, harus ada kerelaaan dari pihak suami untuk menerima tebusan, dan kesanggupan dari pihak istri untuk membayar tebusan tersebut. Namun dengan catatan, nominal harga tebusan tidak boleh

22 Muhammad Abu Zahrah, Ahwal Syabkshiyyah, (Kairo: Daar el-Fikri, 2005), h. 329

23 Mustafa al-Khin dan Musthafa alBugha dalam al-Figh al-Manhaji 'ala Madzhab al-Imam al-Syâfii (Surabaya: Al-Fithrah, 2000), juz IV, h. 127 
melebihi nominal mas kawin pada saat pernikahan.

Bahwa hukum asal khuluk ini ialah mubah jika memenuhi persyaratan. Persyaratan tersebut diantaranya: "Apabila seorang perempuan benci terhadap suaminya karena penampilannya yang jelek, atau perlakuannya yang kurang baik, sementara ia takut tidak akan bisa memenuhi hak-hak suaminya, maka boleh baginya untuk mengajukan khuluk dengan membayar ganti rugi atau tebusan."

Ada juga motif lain dari khulu' yang bisa mengubah hukumnya, seperti jika suami melalaikan hukum Allah, semisal meninggalkan shalat, atau lainnya, maka hukum khuluk menjadi wajib; Sebaliknya, jika tidak ada motif atau alasan apa pun yang mendasarinya, maka khuluk hukumnya haram. Khulu' dapat juga berarti fida atau tebusan, karena isteri meminta cerai kepada suaminya dengan membayar sejumlah tebusan atau imbalan; ${ }^{24}$

Menurut al-Malibariy, khulu' adalah perceraian dengan tebusan dari pihak isteri diberikan pada pihak suami, dengan memakai kata talak atau khulu' atau tebusan. ${ }^{25}$ Khulu' adalah jalan keluar bagi isteri yang tidak menyukai suaminya dengan alasan selain yang biasa melahirkan fasakh, isteri memberikan semacam ganti rugi ('iwad) atas pemberian suami seperti mahar, nafkah, dll, agar suami

${ }^{24}$ H. A. Fuad Said, Perceraian Menurut Hukum Islam, (Jakarta: Pustaka Al-Husna, 1994), h. 95

${ }^{25}$ Syeikh Zainuddin bin Abdul Aziz alMalibariy, Fath al-Mu'in Syarh Qurrat al-Aini, (Semarang: Pustaka Alawiyyah, 1997), h. 111 bersedia dengan rela hati menjatuhkan talak kepadanya. ${ }^{26}$

Al-Jurzawi ${ }^{27}$ menuturkan: Khulu' sendiri sebenarnya dibenci oleh syari'at yang mulia seperti halnya talak; semua akal dan perasaan sehat menolak khulu', hanya Allah swt., saja Yang Maha Bijaksana memperbolehkannya untuk menolak bahaya ketika tidak mampu menegakan hukum-hukum Allah swt:; Maksudnya Hikmah khulu untuk menghindari bahaya, yakni saat terjadinya pertengkaran hebat yang menimbulkan gejolak dalam hubungan suami isteri hingga keduanya tidak bisa disatukan lagi dalam ikatan rumah tangga maka khulu' diperbolehkan; Hal ini agar keduanya tetap berjalan dalam kehidupan masing-masing dan menjalankan kewajibannya sebagai hamba Allah. ${ }^{28}$

Hikmah yang terkandung didalamnya sebagaimana telah disebutkan adalah untuk menolak bahaya yaitu apabila perpecahan suami isteri telah memuncak dan dikhawatirkan keduanya tidak dapat menjaga syarat-syarat dalam kehidupan suami isteri, maka khulu' dengan cara-cara yang telah ditetapkan oleh Allah Yang Maha Bijaksana merupakan penolak terjadinya pernusuhan dan untuk menegakan hukum-hukum Allah; oleh karena itu, Allah berfirman:

26 Abdul Wahhab Muhaimin, "Kajian Ayat-Ayat Hukum Wanita Dalam Perkawinan Dan Perceraian", Jurnal Abkam, No. 4 (Maret 1998), h. 44

27 Ali Ahmad Al-Jurzawi, Hikmah atTasyri' wa Falsafatuh, (Falsafah Dan Hikmah Hukum Islam), Penerjemah: Hadi Mulyo Dan Sabahus Surur, (Semarang: CV AsSyifa, 1992), h. 320

28 Ali Ahmad Al-Jurjawi, Indahnya Syariat Islam, (Jakarta; Gema Insani, 2006), h. 379 


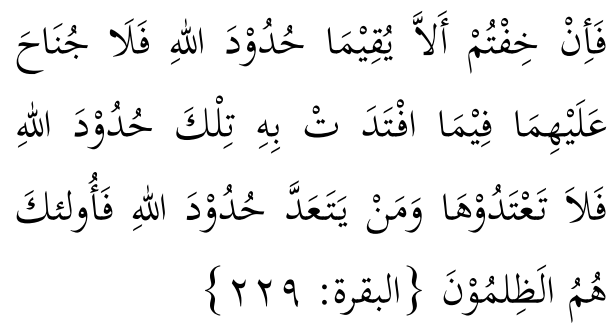

"Kalau keduanya khawatir tidak akan dapat menjalankan bukum-bukum Allah. jikea kamu khawatir babwa keduanya (suami isteri) tidak dapat menjalankan bukum-bukum Allah, Maka tidak ada dosa atas keduanya tentang bayaran yang diberikan oleh isteri untuk menebus dirinya. Itulab bukumbukum Allah, Maka janganlah kamu melanggarnya." (QS. al-Baqarah (2): 229)

Sebahagian besar ulama salaf dan khalaf mengatakan bahwa tidak boleh khulu kecuali terjadi perselisihan dan nusyuz dari pihak isteri; sedangkan Syafi'i berpandangan bahwa khulu' itu boleh dalam kondisi perselisihan dan keharmonisan, namun khulu' dalam kondisi pertama adalah lebih utama dan sesuai dengan yang ia pilih. $^{29}$

Kedudukan kbulu' di dalam hukum keluarga menurut mazhab Umar, Usman dan Ali ra serta jumhur fuqaha', bahwa khulu' termasuk talak, seperti halnya pendapat Abu Hanifah dan AlMuzanniy mempersamakan khulu' dengan talak; sedangkan Imam Syafi'i berpendapat bahwa khulu termasuk fasakh di dalam qaul qadimnya. ${ }^{30}$ Demikian juga pendapat

29 Muhammad Nasib ar-Rifa'i, Kemudahan Dari Allab Ringkasan Tafsir Ibnu Katsir, (Jakarta: Pustaka Al-Kautsar, 1997) Jil. 1, h. 376

30 Muhammad bin Muhammad Abu Hamid Al-Ghazali, al-Wajiz fi Fiqh Mazhab
Imam Ahmad dan Daud, serta Ibnu Abbas dari kalangan sahabat. Imam Syafi'i juga meriwayatkan bahwa khulu' merupakan kata sindiran; Jadi jika dengan kata kinayah tersebut menghendaki talak, maka talak pun terjadi, dan jika tidak maka menjadi fasakh; akan tetapi dalam qaul jadidnya dikatakan bahwa khulu' itu adalah talak. ${ }^{31}$

Pada umumnya perceraian itu terjadi karena faktor-faktor tertentu yang mendorong suami-istri untuk bercerai; ${ }^{32}$ faktor-faktor dimaksud antara pasangan suami-istri yang satu dengan yang lain saling berbeda. Berdasarkan penelitian yang pernah dilakukan pada tahun 1966 dengan mengambil sampel 600 pasangan suami-istri yang mengajukan perceraian menunjukkan bahwa keluhankeluhan yang menjadi faktor penyebab terjadinya perceraian adalah. ${ }^{33}:$ a) pasangannya sering mengabaikan kewajibannya terhadap rumah-tangga dan anak, seperti jarang pulang ke rumah, tidak adanya kedekatan emosional dengan anak dan pasangan; b) masalah keuangan yang tidak mencukupi untuk kebutuhan keluarga; c) adanya penyiksaan fisik terhadap pasangan, sering membentak, mengeluarkan kata-kata kasar dan menyakitkan; mempunyai wanita idaman lain; d) sering menolak dan tidak bisa memberikan kepuasan dalam masalah hubungan seksual, Sering

Imam Syafi'i, (Beirut: Daar el-Fikri, 2004), h. 276

31 Imam asy-Syafi'i, al-Umm, (Beirut: Dar al-Fikri, 2002), Jil. 3, h. 220

32 Lihat Ihromi, Bunga Rampai Sosiologi Keluarga, (Jakarta: Yayasan Obor, 1999), h. 153-155

33 Ihromi, Bunga Rampai Sosiologi Keluarga, Ibid. h. 153-155 
mabuk, campur tangan dan tekanan sosial dari pihak kerabat; e) seringnya muncul kecurigaan, kecemburuan terhadap pasangannya; jarang berkomunikasi, kurang perhatian dan kebersamaan di antara pasangan; f) tuntutan yang dianggap terlalu berlebihan, tidak sabar, tidak ada toleransi dan dirasakan terlalu menguasai

Perceraian merupakan titik puncak dari pengumpulan berbagai permasalahan yang menumpuk beberapa waktu sebelumnya dan jalan terakhir yang harus ditempuh ketika hubungan perkawinan itu sudah tidak dapat dipertahankan lagi. ${ }^{34}$ Faktor Penyebabnya adalah: ${ }^{35}$ a) ketidaksetiaan pasangan hidup, karena terdapat orang ketiga yang menggangu kehidupan perkawinan. Bila diantara keduannya tidak sepakat untuk menyelesaikan dan tidak saling memaafkan, akhirnya percerainlah jalan terbaik untuk mengakhiri hububungan pernikahan itu; b) tekanan kebutuhan ekonomi keluarga, Harga barang dan jasa yang semakin melonjak tinggi karena faktor krisis ekonomi negara yang belum berakhir, sementara itu gaji atau penghasilan pas-pasan dari suami sehingga hasilnya tidak cukup untuk memenuhi kebutuhan keluarga. Agar dapat menyelesaikan masalah itu, kemungkinan seorang istri menuntut cerai dari suaminya; c) tidak mempunyai keturunan juga dapat memicu permasalahan diantara kedua pasangan, guna menyelesaikan masalah keturunan ini mereka sepakat untuk

34 Agoes Dariyo, Psikologi Perkembangan Dewasa Muda, (Jakarta: PT Gramedia Widiasarana, 2003), h. 160

${ }^{35}$ Agoes Dariyo, Psikologi Perkembangan Dewasa Muda, Ibid. h. 160 mengakhiri pernikahan itu dengan bercerai; d) perbedaan prinsip hidup dan agama.

Hasil penelitian banding 36 didapatkan bahwa faktor-faktor penyebab yang mempengaruhi perceraian adalah: kurangnya kesiapan mental; permasalahan ekonomi; kurangnya komunikasi antar pasangan; campur tangan keluarga pasangan; dan perselingkuhan.

Adapun dalam hal cerai gugat, seperti dalam doktrin fiqh, setiap permohonan cerai yang diajukan oleh isteri itu tidak harus selalu berbentuk khulu' yang diikuti dengan pembayaran iwad, tetapi dengan alasan-alasan tertentu yang telah diatur dalam perundangundangan yakni Pasal 39 ayat (2) UU No. 1/1974, pasal 19 PP No. 9/1975 Pasal 116 dan 51 KHI, yaitu:

a. Suami berbuat zina, menjadi pemabuk, pemadat, penjudi dan sebagainya yang sukar disembuhkan;

b. Suami meninggalkan isteri selama 2 tahun tanpa izin isteri dan tanpa alasan yang sah atau karena hal lain di luar kemampuannya;

c. Suami mendapatkan hukuman penjara 5 tahun atau lebih berat;

d. Suami melakukan kekejaman atau penganiayaan;

e. Suami mendapat cacat badan atau penyakit dengan akibat tidak dapat menjalankan kewajibannya sebagai suami;

f. Antara suami-isteri terus-menerus terjadi perselisihan dan pertengkaran

${ }^{36}$ Lihat Sulistyawati, "Faktor Determinan Penyebab Terjadinya Perceraian dalam keluarga", Tesis, (Bandung: PPs Psikologi ITB, 2003), h. 28 
g. Suami melanggar taklik talak dan atau perjanjian perkawinan.

Alasan yang dapat dijadikan dasar, alasan gugatan di Pengadilan Agama diatur di dalam UU Perkawinan dan Kompilasi Hukum Islam, antara lain:

a. Suami berbuat zina, pemabuk, pemadat, penjudi dan sebagainya yang sukar disembuhkan;

b. Suami meninggalkan penggugat selama 2 (dua) tahun berturutturut tanpa ada izin atau alasan yang sah. Artinya, suami dengan sadar dan sengaja meninggalkan penggugat;

c. Suami dihukum penjara selama (lima) 5 tahun atau lebih setelah perkawinan dilangsungkan;

d. Suami bertindak kejam dan suka menganiaya, sehingga keselamatan penggugat terancam;

e. Suami tak dapat menjalankan kewajibannya sebagai suami karena cacat badan atau penyakit;

f. Terjadi perselisihan dan pertengkaran terus menerus tanpa kemungkinan untuk rukun kembali;

g. Suami melanggar taklik-talak yang diucapkan saat ijab-kabul;

h. Suami beralih agama atau murtad yang mengakibatkan ketidak harmonisan dalam keluarga. ${ }^{37}$ Untuk mendukung gugatan cerai, harus disiapkan surat-surat dan saksi-saksi yang akan dijadikan alat bukti untuk menguatkan gugatan cerai. ${ }^{38}$

37 Inpres no.1 tahun 1991, Kompilasi Hukum Islam di Indonesia,Pasal 16

38 Keputusan Mahkamah Agung Nomor 001/SK/1991 tanggal 24 Januari 1991 dan Surat Keputusan Mahkamah Agung Nomor 43/TUADA-AG/IIIUM/XI/1992 tentang Prosudur pengajuan perkara
2. Dampak yang timbul Akibat Cerai Gugat

Secara spesifik dampak perceraian bagi suami atau istri berada pada sisi psikologis. Pada sisi ini, akibat dari perceraian akan dapat melahirkan beberapa implikasi ${ }^{39}$

a. Hilangnya rasa aman dan nyaman. Seperti apapun kuatnya seorang pria atau wanita, siapapun yang mengajukan gugatan perceraian namun hal itu justru akan menjadi boomerang bagi dirinya. Pada perspektif ini, yang melakukan gugatan justru akan merasakan sebuah hilangnya rasa aman dan nyaman ketika sendiri ataupun ketika dengan pasangan keduanya. Rasa aman itu tidak lain adalah rasa nyaman yang telah dibangun bersama-sama dengan pasangan pilihan hatinya yang pertama kali, sedangkan kondisi diri atau rumah tangga yang baru tidaklah ditemukan kenyamanan di masa lalunya.

b. Rasa bersalah atau dosa besar. Ketidaknyamanan itu adalah wujud dari sebuah rasa bersalah karena telah meninggalkan pasangan dan anak-anak yang selama ini telah mewarnai kehidupannya dengan lebih memilih kehidupan barunya ataupun orang lain. Akhirnya dengan sendirinya mereka yang melakukan gugatan cerai akan merasakan sebuah tekanan hidup

39 Lihat hasil wawancara el-mlipaki dengan Nani Kartikaningsih seorang psikolog pada RSJ Kota Semarang, dalam bttp:/ / alfinlatife.blogspot.com/2012/08/dampa k-perceraian-secara-psikologi.html, diakses pada hari Senin, 03 Agustus 2015, Pukul. 17.25 WIB 
(stres) yang berasal dari keputusan dia sendiri.

c. Hilangnya rasa nikmat. Pada sebuah kasus perceraian karena poligami atau adanya pihak ketiga, bisa dimungkinkan akan munculnya ketiadaan kenikmatan dalam berhubungan intim dengan pasangan barunya, penyebabnya muncul karena teringat dengan keluarganya yang dahulu yang telah ditinggalkan; sedangkan yang biasanya dirasakan oleh seorang isteri adalah sebuah rasa sakit yang mendalam karena ditinggalkan oleh seorang suami yang dicintainya; oleh karenanya bisa memunculkan rasa antipati terhadap setiap laki-laki yang akan mendekatinya, dan akhirnya lebih memilih hidup sendiri dan mengurus anak-anaknya sebagai obat kesepian.

Ada beberapa masalah yang akan timbul pada diri masing-masing pasangan yang bercerai, yakni: ${ }^{40}$

a. Masalah ekonomi. Setelah perceraian, suami maupun istri akan mengalami pengurangan pemasukan, karena penghasilan suami kini harus menafkahi dua rumah tangga. Sering, para wanita yang bercerai harus mencari pekerjaan untuk menyokong tunjangan yang mungkin diberikan suami, dan untuk memenuhi biaya hidup anak-anaknya.

b. Masalah praktis. Walaupun suami hanya membantu beberapa tugas rumah tangga sebelum perceraian, masalah ini pun dapat

40 Lihat Reni Hawadi Akbar, Psikologi Perkembangan Anak: Mengenal Sifat, Bakat, dan Kemampuan Anak, (Jakarta: Gramedia Widiasarana Indonesia, 2001), h. terjadi, karena kini istri harus bertanggung jawab sendiri terhadap semua pekerjaan rumah tangga.

c. Masalah psikologis. Baik pihak wanita maupun pria, setelah perceraian mereka cenderung merasakan perasaan-perasaan seperti perasaan tak menentu dan kehilangan identitas. Masalahmasalah ini lebih banyak terjadi pada wanita, yang tadinya mengasosiasikan identitasnya dengan identitas suaminya.

d. Masalah emosional. Pada banyak wanita, perasaan-perasaan seperti rasa bersalah, rasa malu, kebencian dan dendam, kemarahan, serta kecemasan terhadap masa depan biasanya menjadi sangat dominan dalam diri mereka, bahkan dapat mengubah kepribadiannya.

e. Masalah sosial. Wanita yang bercerai biasanya merasa ditinggalkan, dan menjadi "terkunci" dalam dunia bersama anak-anak mereka. Kehidupan sosial mereka hanya terbatas pada aktivitas bersama kerabat dan teman-teman dari jenis kelamin yang sama.

f. Masalah karena kesepian. Ketika telah terbiasa berada dalam companionship dengan pasangan, wanita (dan pria) yang bercerai akan merasa kesepian ketika mereka kehilangan companionship dari seseorang yang memiliki nilai-nilai dan ketertarikan yang sama.

g. Masalah karena pembagian hak pengasuhan anak. Ketika hak pengasuhan anak dibagi kepada kedua orang tua setelah bercerai, masing-masing orang tua yang bercerai akan mengalami 
kesulitan dalam penyesuaian, baik terhadap diri mereka sendiri maupun anak-anak mereka. Masalah terjadi ketika misalnya, anak tidak patuh pada satu orang tua, setelah ia berada bersama orang tua yang lain.

h. Masalah seksual. Setelah bercerai, kedua belah pihak masingmasing akan merasa kekurangan aktivitas seksual yang biasa dilakukan, kecuali mereka menikah lagi segera setelah bercerai. Wanita yang memiliki anak biasanya akan kesulitan untuk memikirkan alternatif ini, sehingga interval waktu setelah bercerai dan menikah kembali (remarried) cenderung lebih panjang pada wanita daripada pria.

i. Masalah-masalah perubahan konsep diri. Tanpa memperhatikan pihak mana yang menimbulkan masalah yang mengakibatkan perceraian, kedua belah pihak biasanya akan merasakan rasa kegagalan karena pernikahan mereka tidak berhasil, dan merasakan perasaan benci atau dendam terhadap satu sama lain. Perasaan-perasaan ini, tanpa bisa dihindari, akan mewarnai konsep diri mereka yang mengarah kepada perubahan kepribadian.

Dampak yang paling dominan dirasakan pasca perceraian adalah pada diri anak. Dalam keluarga manapun perceraian akan menjadi suatu penyesuian diri bagi seorang anak yang harus tinggal dengan salah satu dari orang tua mereka. Reaksi anak terhadap perceraian orang tuanya sangat dipengaruhi oleh cara orang tua berperilaku sebelum, selama dan sesudah perceraian. Anak akan membutuhkan dukungan, kepekaan, dan kasih sayang yang lebih besar untuk membantunya mengatasi kehilangan yang dialami selama masa sulitnya. Mereka mungkin akan menunjukkan kesulitan penyesuaian diri dalam bentuk perilaku, kesulitan belajar, atau berkurangnya interaksi dengan orang-orang di lingungan sekitar tempat tinggalnya.

Dampak perceraian dapat dilihat dari tingkah laku anak yang sangat jauh berbeda dengan sikapnya sebelum kedua orang tuanya bercerai. Tingkah laku mereka yang sering ditunjukkan setelah orang tua bercerai tersebut antaralain suka mengamuk, menjadi kasar, agresif, menjadi pendiam, tidak lagi ceria, tidak suka bergaul, sulit berkonsentrasi dan tidak berminat pada tugas sekolah sehingga prestasi disekolah cenderung menurun, serta suka melamun terutama mengkhayalkan orang tuanya akan bersatu lagi.

Dampak dari adanya percerain tersebut bagi anak adalah; ${ }^{41}$ selain akan merusak akhlak juga berkurangnya adab (pada diri anakanak), hal ini merupakan asal-muasal munculnya penyakit (sosial) dan sebab dari segala cobaan dan kesengsaraan."

Tidak dapat disangkal bahwa anak akan sedih bila mereka menyaksikan perkelahian orang tuanya terlebih bila pertengkaran tersebut menyebabkan perceraian. Kurangnya perhatian orang setelah perceraian juga akan mempengaruhi

41 'Ali Ahmad al-Jarjawi, Hikmah atTasyri' wa Falsafatubu, (Beirut: Dar al-Fikr, t.th), Juz. 2, h. 58 
perkembangan jiwa anak; anak akan merasa kasih sayang orang tua yang didapatkan tidak utuh, anak akan mencari perhatian dari orang lain atau bahkan ada yang merasa malu, minder, dan tertekan; Anak-anak tersebut umumnya akan mencari pelarian dan tidak jarang yang akhirnya terjerat dengan pergaulan bebas dan narkoba.

Hal yang paling berat dalam kasus perceraian adalah bagaimana memulihkan kembali hubungan yang baik dan menciptakan keakraban lagi antar kedua orang tua. Pengaruh orang tua dapat menciptakan kekuatan pada diri anak, meskipun kasus perceraian itu tetap membawa dampak dalam perkembangan sosial dan emosi anak. Fakta di lapangan membuktikan bahwa mayoritas anak-anak nakal merupakan anakanak yang berasal dari keluarga broken home. ${ }^{42}$

Kenakalan mereka tersebut sangatlah masuk akal. Akibat tekanan batin yang dialami karena perceraian orang tua menyebabkan

42 Wulan Saripah mengutip bahwa, bahwa $63 \%$ dari anak nakal dalam suatu lembaga pendidikan anak-anak delikuen berasal dari keluarga-keluarga yang tidak teratur, tidak utuh atau mengalami tekanan hidup yang terlampau berat. Meril mendapatkan 50\% dari anak delikuen (anak-anak yang menyeleweng) berasal dari keluarga broken bome. Menurut hasil penelitian Lembaga Penyelidikan Pendidikan IKIP Bandung tahun 1959 dan 1960 menyatakan sekurang-kurangnya 50\% dari anak nakal di Prayuwana dan Penjara Anak-anak di Tangerang berasal dari keluarga-keluarga yang tidak utuh. Lihat Wulan Saripah, "Profil Interaksi Sosial Peserta Didik Broken Home dan Implikasinya Terhadap Layanan Bimbingan Dan Konseling", Tesis, Universitas Pendidikan Indonesia, Bandaung, 2013, h. 4 mereka mencari jalan pintas untuk mencari kesenangan hanya sekedar untuk melupakan permasalahan dalam keluarga mereka, meskipun hal tersebut hanya berupa kesenangan sesaat; selain itu banyak pula anak yang duluya berprestasi disekolah kemudian menjadi malas bahkan tidak berprestasi sama sekali, hal tersebut dapat disebabkan karena hilangnya motivator yakni orang tua mereka yang selalu memberikan semangat untuk anakanaknya sewaktu keluarga masih harmonis. Dengan tidak adanya penyemangat tersebut merekapun berpikir bahwa semua yang dia lakukan akan sia-sia karena sebesar apapun prestasi yang akan mereka capai tidak akan membuat orang tua mereka bersatu kembali dan membangun keluarga yang harmonis seperti dulu.

Seorang anak yang orang tuanya telah bercerai seringkali melamun dan mengkhayalkan orang tua mereka bersatu lagi, dalam lamunan tersebut terkadang banyak perasaan yang menghampiri seperti perasaan sedih karena kehidupan indah dalam keluarga sudah tidak dirasakan lagi seperti dulu sebelum orang tua bercerai, perasaan marah karena menganggap tuhan tidak adil terhadap hidupnya yang tidak seindah keluarga-keluarga lain, dan perasaan bersalah karena dia berpikir bahwa orang tuanya bercerai disebabkan oleh dirinya. Tidak jarang juga perasaan tidak nyaman akan menghampiri seorang anak terutama pada remaja yang orang tuanya bercerai.

\section{Kesimpulan}

Berdasarkan pemaparan data lapangan, serta analisis yang telah 
dilakukan, maka dapat dirumuskan simpulan sebagai berikut:

1. Faktor utama penyebab cerai gugat yang dominan terjadi di Pengadilan Agama adalah faktor ekonomi, berupa kurang atau tidak terpenuhinya kebutuhan ekonomi keluarga, sebagai akibat kurang atau tidak adanya tanggung jawab suami dalam rumah tangga. Kemudian faktor percekcokan, kekerasan dalam rumah tangga, merupakan faktor berikutnya yang cukup dominan. Selain kedua hal tersebut, faktor perselingkuhan dan poligami di beberapa perkara cerai gugat yang terjadi, menjadi faktor penyebabnya; demikian juga judi dan mabuk-mabukkan menjadi faktor penyebab yang mewarnai perkara cerai gugat di 3 Pengadilan Agama.

2. Dampak utama dari perceraian (khususnya cerai gugat) adalah terganggunya kenyamanan baik suami atau istri dan anggota keluarga khususnya anak-anak mereka. Dampak negatif dari perceraian (khususnya cerai gugat) tersebut jika terus naik grafiknya secara kualitatif disetiap tahun, berdampak buruk bagi keberlangsungan keluarga yang harmonis bahkan pada sektor stabilitas sosial, karena dapat membentuk anggota keluarga menjadi broken bome, yang kemudian membentuk mentalmental yang tidak baik dan rapuh sehingga berkemungkinan mempraktikkan perbuatanperbuatan negatif.

\section{Daftar Pusta}

'Ali Ahmad al-Jarjawi, Hikmah atTasyri' wa Falsafatubu, (Beirut: Dar al-Fikr, t.th), Juz. 2,
A. W. Munawwir, Al-Munawwir: Kamus Arab-Indonesia, (Surabaya: Pustaka Progresif, 1997), Cet. 14 ,

Abdul Wahhab Muhaimin, "Kajian Ayat-Ayat Hukum Wanita Dalam Perkawinan Dan Perceraian", Jurnal Abkam, No. 4 (Maret 1998),

Abu Mansur, Lisan el-Arab, (Kairo: Daar el-Hadis, 2003), Jil. 3,

Agoes Dariyo, Psikologi Perkembangan Dewasa Muda, (Jakarta: PT Gramedia Widiasarana, 2003),

Ali Ahmad Al-Jurjawi, Indabnya Syariat Islam, (Jakarta; Gema Insani, 2006),

, Hikmah at-Tasyri' wa Falsafatuh, (Falsafah Dan Hikmah Hukum Islam), Penerjemah: Hadi Mulyo Dan Sabahus Surur, (Semarang: CV As-Syifa, 1992),

Amiruddin dan Zainal Asikin, Pengantar Metodologi Penelitian Hukum, (Jakarta: PT. Raja Grapindo Persada, 2003),

Bambang Sunggono, Metode Penelitian Hukum, (Jakarta: Raja Grafindo Persada, 2001),

Djamaan Nur, Fiqh Munakahat, Dina Utama Semarang, Cet. I, 1993,

Djamal latiief, H.M, Aneka Hukum Percerian di Indonesia, Jakarta, Ghalia Indonesia, 1982,

H. A. Fuad Said, Perceraian Menurut Hukum Islam, (Jakarta: Pustaka Al-Husna, 1994), 
Harian Lampung Post, Kamis, 02 Mei 2015 ,

Harian Lampung Post, Kamis , 5 januari 2016,

ht://www.pa-

tanggamus.go.id/index.php/rekapperkara-diterima, Akses 25 Oktober 2014

http:/ / alfinlatife.blogspot.com/2012/08/da mpak-perceraian-secara-

psikologi.btml, diakses pada hari Senin, 03 Agustus 2015, Pukul. 17.25 WIB

http://lampost.co/berita/angkaperceraian-di-lampung-barattinggi, Akses 07 Januari 2014

http://lampost.co/berita/pns-dimetro-dan-lamtim-banyakyang-bercerai, Akses 25 Okt 2014

Idris Al-Marbawi, Kamus Bahasa Arab Melayu, (Surabaya: Hidayah, 2000), Jil. 1,

Ihromi, Bunga Rampai Sosiologi Keluarga, (Jakarta: Yayasan Obor, 1999),

Imam asy-Syafi'i, al-Umm, (Beirut: Dar al-Fikri, 2002), Jil. 3,

Instruksi Presiden RI no. 1 tahun 1991, Kompilasi Hukum Islam di Indonesia, Dirjen Binbaga Islam, Kemenag RI tahun 2001

Iskandar, Metodologi Penelitian Pendidikan dan Sosial; Kualitatif dan Kuantitatif, (Jakarta: Gaung Persada Press, 2008),
J.Supranto, Metode Penelitian Hukum dan Statistik, (Jakarta: PT. Rineka Cipta, 2003),

Jalaluddin al-Mahalli, Al-Mahalli, juz III (Indonesia: Nur Asia, tt),

Keputusan Mahkamah Agung Nomor 001/SK/1991 tanggal 24 Januari 1991 dan Surat Keputusan Mahkamah Agung Nomor 43/TUADA-AG/IIIUM/XI/1992 tentang Prosudur pengajuan perkara

Khoiruddin Nasution, Hukum Perdata (Keluarga) Islam Indonesia, dan Perbandingan Hukum Perkawinan di Dunia Muslim, ACAdeMIA, Tazzafa, Yogyakarta, 2009,
------, Hukum Perkawinan 1, ACAdeMIA, \& Tazzafa, Yogyakarta, 2005,

Lexi. J. Moloeng, Metode Penelitian Kuantatif, (Bandung: Remaja Rosda Karya, 2002),

-------, Metodologi Penelitian Kualitatif Edisi Revisi, (Bandung: Remaja Rosdakarya, 2009),

Louis Gootshalk, Understanding Historya Primer of Historical Method, alih bahasa oleh Nogroho Noto Susanto, (Jakarta, UI Press, 1985),

Muhammad Abu Zahrah, Abwal Syabkshiyyah, (Kairo: Daar elFikri, 2005),

Muhammad bin Muhammad Abu Hamid Al-Ghazali, al-Wajiz fi Fiqh Mazhab Imam Syafi', (Beirut: Daar el-Fikri, 2004), 
Muhammad Nasib ar-Rifa'i, Kemudahan Dari Allab Ringkasan Tafsir Ibnu Katsir, (Jakarta: Pustaka AlKautsar, 1997) Jil. 1,

Mustafa al-Khin dan Musthafa alBugha dalam al-Figh al-Manbaji 'ala Madz̧ab al-Imam al-Syâfíi (Surabaya: Al-Fithrah, 2000), juz IV,

Nasution, Metode Research:: Penelitian Ilmiah, (Jakarta: Bumi Aksara, 1996), Cet. Ke-2,

Pasal 1 Undang-undang Perkawinan No. 1 tabun 1974

Reni Hawadi Akbar, Psikologi Perkembangan Anak: Mengenal Sifat, Bakat, dan Kemampuan Anak, Jakarta: Gramedia Widiasarana Indonesia, 2001),

Soerdjono Soekanto, Penelitian Hukum Normatif, (Jakarta: PT. Raja Grafindo, 2003),

Sugiyono, Memahami Penelitian Kualitatif, (Bandung: Alfabeta, 2015),

-------, Metode Penelitian Kuantitatif, Kualitatif dan R\&D, (Bandung: LFABETA, 2008), Cet. IV,

Sulistyawati, "Faktor Determinan Penyebab Terjadinya Perceraian dalam keluarga", Tesis, (Bandung: PPs Psikologi ITB, 2003),

Sutrisno Hadi, Metodologi Research, (Yogyakarta: Fakultas Teknologi UGM, 1996,

Syeikh Zainuddin bin Abdul Aziz alMalibariy, Fath al-Mu'in Syarb
Qurrat al-Aini, (Semarang: Pustaka Alawiyyah, 1997),

Taqiyyuddin Abi Bakr, Kifayatul Akbyar fie Hilli Ghayah al-Ikhtishar, Dar al-Kutub al-Islamy, tt,

Undang-undang No.23 tahun 2004 tentang Penghapusan Kekerasan dalam Rumah Tangga,.

Wulan Saripah, "Profil Interaksi Sosial Peserta Didik Broken Home dan Implikasinya Terhadap Layanan Bimbingan Dan Konseling”, Tesis, Universitas Pendidikan Indonesia, Bandaung, 2013,

Yayasan Penyelenggara Penterjemah Al-Qur'an kementerian Agama RI, Al-Qur'an dan Terjemahnya, Jakarta, PT. Tehazed, 2010, 